\title{
細菌免疫における不完全抗体の研究
}

\author{
堀川高大 \\ 東京医科歯科大学 口腔細菌学教室 \\ (昭和 36 年 8 月 2 日受付)
}

\section{On the Incomplete Antibodies in Various Anti-bacterial Immune Sera}

\author{
by \\ Takahiro Horikawa \\ Department of Microbiology, Tokyo Medical and Dental University
}

はしがき

最近の医学の進歩は誠に目覚しいものがあり, 疾病とその予防並びに治療の核相は戦前に比し全 く一変したといつても過言ではなかろう。伝染性 疾患のみとりあげても，結核は往時の偉力を失 い，腸チフスは殆んど影を潜めるに至つた。その 主な原因として予防接種のごとき公衆衛生学的の 普及も勿論ではあるが，抗生物質や化学療法剤 が，相ついで発見され治療に応用されたためであ る事を疑う人はあるまい。しかしその反面いわゆ る菌交代現象の出現による真菌症のごとき従来余 り返り見られなかつたものが，実際には重要な疾 病として登場するに至つた。つまり腸チフス菌や 赤痢菌の場合でも最も論議されるのは薬剤耐性菌 の出現であり，その対策が急がれておる所以であ る。

一方細菌免疫学においても感染の様式が変化す れば自ら抗体産生等も変化するのは当然であつ て, 完全な腸チフス症が稀有の現在では，抗生剤 投与の為昔より最も有用な免疫血清診断法であつ た，かの Widal 反応等もその有用性を失いつつ あると考えても差支えはないであろう。よつて私 は腸内細菌類による感染や免疫によつて不完全抗 体の検出を行い, 従来より施行されている完全抗
体のそれと比較対照し，その意義について考察を 試みた次第である。

\section{○不完全抗体について}

従来の沈降反応や凝集反応として認められる抗 体を完全抗体 complete antibody と呼び, 沈降や 凝集を示さないが，抗原と結合する抗体を不完全 抗体 incomplete antibody という。後者はまた非 沈降抗体 non-precipitating antibody ともいわ扎 る。緒方は定型抗体と非定型抗体と呼ぶ事を主張 しているし，抗原との結合価から完全抗体を二価 抗体 bivalent antibody 不完全抗体を univalent antibody と呼ぶ学者もあり，またその様に記載さ れた書物も多い。両者の差異を簡単に表示すれば 第 1 表のごとくになる。これは Rh 因子について の比較であるが他の場合にも大体適用される。し たがつてその性状は Rh 因子のごとき血液型抗体 において最も詳細に研究されており，また新生児 の血液疾患の原因として注目されている。

\section{○不完全抗体の検查法}

(1) 抗グロブリン試験 (antiglobulin test) いわゆるクームス試験 (Coombs'test) として知 られているもので原法は Antihuman globulin Serum と人血球を用いるものであるが，われわれ の場合は免疫して作つた Antiglobulin serum と 細菌を用いるので modified Coombs' test と称す 
表 1 A.S. Wiener(11949)による

\begin{tabular}{|c|c|c|}
\hline 抗体の名称 & $\begin{array}{l}2 \text { 価抗 体 } \\
\left(\begin{array}{l}\text { bivalent } \\
\text { antibody }\end{array}\right)\end{array}$ & $\begin{array}{c}1 \text { 価抗 体 } \\
\left(\begin{array}{l}\text { univalent } \\
\text { antibody }\end{array}\right)\end{array}$ \\
\hline $\begin{array}{l}\text { 免疫による抗体 } \\
\text { 出現の時期 }\end{array}$ & $\begin{array}{l}\text { 早い } \\
\text { (earlys antibody) }\end{array}$ & $\begin{array}{l}\text { 遅い } \\
\text { (late antibody) }\end{array}$ \\
\hline $\begin{array}{l}\text { 熱に対する抵抗 } \\
\text { 性 }\end{array}$ & 比較的不安定 & $\begin{array}{l}\text { 比較的安定耐熱 } \\
\text { 性 }\end{array}$ \\
\hline $\begin{array}{l}\text { 食塩水中での血 } \\
\text { 球との応 }\end{array}$ & 凝集反応示す & $\begin{array}{l}\text { 凝集反応を示さ } \\
\text { ないが血球と結 } \\
\text { 合する }\end{array}$ \\
\hline $\begin{array}{l}\text { 血漿或は血清中 } \\
\text { での血球との反 } \\
\text { 忘 }\end{array}$ & 凝集反応を示す & $\begin{array}{l}\text { 膠着反応により } \\
\text { 血球凝集すき! } \\
\text { (Conglutination) }\end{array}$ \\
\hline $\begin{array}{l}\text { 新生览赤芽球症 } \\
\text { 時の役割 } \\
\text { (Erythroblastosis) } \\
\end{array}$ & ない & 大いにある \\
\hline 胎盤の通過性 & $\begin{array}{l}\text { 正常胎盤を通過 } \\
\text { 出来なと }\end{array}$ & 通過しやすい \\
\hline 免疫反応 & 沈降性抗体 & 防禦抗体 (?) \\
\hline 化学的性状 & englobulin & pseudoglobulin \\
\hline 分子量 & 930,000 & 155,000 \\
\hline
\end{tabular}

表 2 細菌菌液を使用した Proteus 0X19 blocking test

OX 菌液 (MC. No. 5) 可検血清 $\left(56^{\circ} \mathrm{C} 30\right.$ 分非働化)

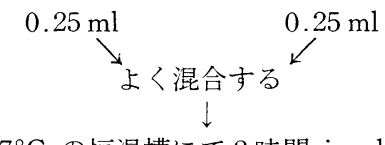

$37^{\circ} \mathrm{C}$ の恒温槽にて 2 時間 incubate $\downarrow$

遠沈後細菌凝集反応判定

細菌凝集反応陰性のものを生理食 塩水で 3 回洗滌後上清をすてる

沈澱菌体に 2 単位の凝集素を含む免疫上清を $0.5 \mathrm{ml}$ $156^{\circ} \mathrm{C} 30$ 分非働化したもの）を加へよく混合する

$37^{\circ} \mathrm{C}$ 恒温槽にて 2 時間 incubate 後

$$
\text { 判 定 }
$$

可きものである。

(2) ブロッキング試験 (Blocking test)

細菌体とそれに対する不完全抗体を結合せし め, 洗滌後凝集素血清を加えて凝集が阻止される か否かを見るもので，上記の坑グロブリン試験と Łもに不完全抗体の検出によく使用されるもので
$0.5 \% 0 \times 19$ 多糖体 感作血球浮游液

$0.25 \mathrm{ml}$

$$
\searrow
$$$$
\text { よく混合する }
$$

可検血清の各稀釈液 $\left(56^{\circ} \mathrm{C} 30\right.$ 分非動化後鶏 赤血球で吸収したもの) $0.25 \mathrm{ml}$

$37^{\circ} \mathrm{C} 1$ 時間 incubate 15 分ごとに振燙する

遠沈㖟赤血球凝集反応判定 赤血球凝集反応陰性のものを燐酸緩衝生理 食塩水で 3 回遠沈洗条後遠沈上清をすてる $\downarrow$ 沈澱赤血球に新たに燐酸緩衝生理食塩水 $0.25 \mathrm{ml}$ を加えて再び赤血球浮游液とする

$$
\downarrow
$$

2 単位の凝集素を含む免疫血清 $0.25 \mathrm{ml}$ を加へてよ く混合する $\left(56^{\circ} \mathrm{C} 30\right.$ 分非働化後赤血球にて吸収し たもの)

$37^{\circ} \mathrm{C}$ で 2 時間恒温槽で incubate

$$
\text { 判定 }
$$

表 4 Proteus 0X19 多糖体の抽出法

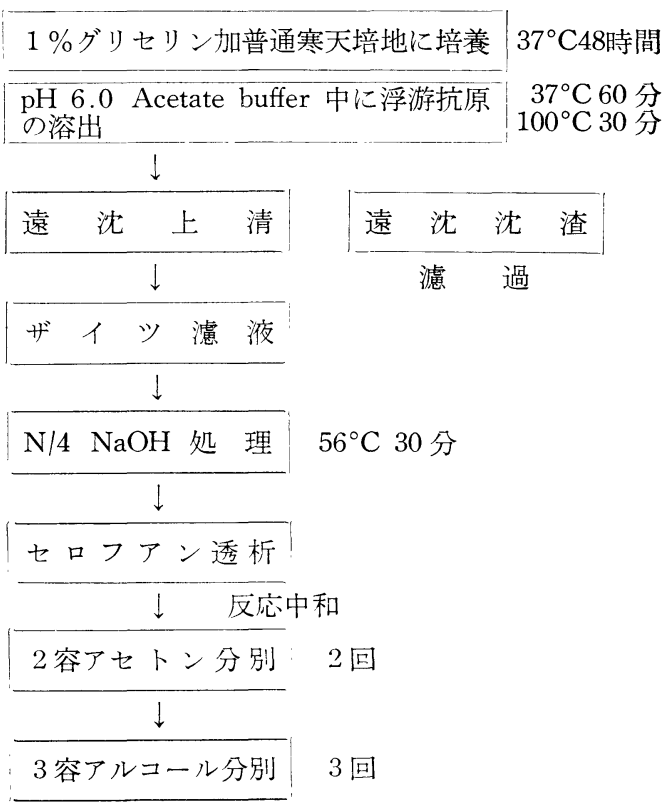


表 5 Proteus $0 \times 10$ 菌体多糖分劃を使用した 免疫家鬼血清の Coombs' test 及び blocking test a）細菌を使用したもの

\begin{tabular}{l|c|c|c|c|c|c|c|c|c}
\hline 血清稀䣋 & 1 & 1 & 1 & 1 & 1 & 1 & 1 & 1 & 対 \\
\hline & $\vdots$ & $\vdots$ & $\vdots$ & $\vdots$ & $\vdots$ & $\vdots$ & $\vdots$ & \\
\hline & 10 & 20 & 40 & 80 & 160 & 320 & 640 & 1280 & 照 \\
\hline 細菌凝集反応 & - & - & - & - & - & - & - & - & - \\
Coombs test & ++ & + & + & + & - & - & - & - \\
blocking test & - & - & - & - & + & + & + & +
\end{tabular}

b) 感作血球を使用したもの

\begin{tabular}{|c|c|c|c|c|c|c|}
\hline & $\left(\begin{array}{c|c|cc}1 & 1 & 1 & 1 \\
\vdots & 1 & \vdots & \vdots \\
10 & 20 & 40 & 80\end{array}\right.$ & $\begin{array}{c}1 \\
\vdots \\
160\end{array}$ & $\begin{array}{c}1 \\
\vdots \\
320\end{array}$ & $\mid \begin{array}{c}1 \\
\vdots \\
640\end{array}$ & $\left|\begin{array}{c}1 \\
\vdots \\
1280\end{array}\right|$ & $\begin{array}{l}\text { 対 } \\
\text { 照 }\end{array}$ \\
\hline 感作血 & --- & - & - & - & - & - \\
\hline Coom & ++++ & + & + & - & - & - \\
\hline blocki & --1 & - & - & + & + & + \\
\hline
\end{tabular}

ある。

(3) Passive hemagglutination test によるもの 進藤，歌橋の創意によるもので Middlebrook Dubos $の$ Passive hemagglutination test と Coombs' test を組合せた複雑な方法であり，結核抗体の証 明に使用された。

Proteus 菌免疫血清での実験に使用した方法を 図示すれば Blocking test は第 2 表。passive hemagglutination による方法は第 3 表のごとくであ る。

\section{○赤痢菌免疫血清について}

赤痢菌を用いてウサギを免疫する場合，不完全 抗体が著明に見られることは Morgan 等 ${ }^{33}$ が指適 しているところであるが，赤痢菌の菌型により大 きな差があり, Sh. dysenteriae 1 (志賀菌)では不 完全抗体価の 4 倍以上にもなり Morgan らの成 績と一致するが Sh. flexneri 2 a では両者の差は 見られない。またここで見られる不完全抗体は感 染防禦能と関係がある様であり，また blocking を示した血清が in vivoにおいて長期間を経て再 検査した時クームス試験価は変らないが， blocking 能を消失している例があり，不完全抗体と blocking 能という問題に興味深い知見であり，ま た中和抗体の本質ともつながるもので極めて重要

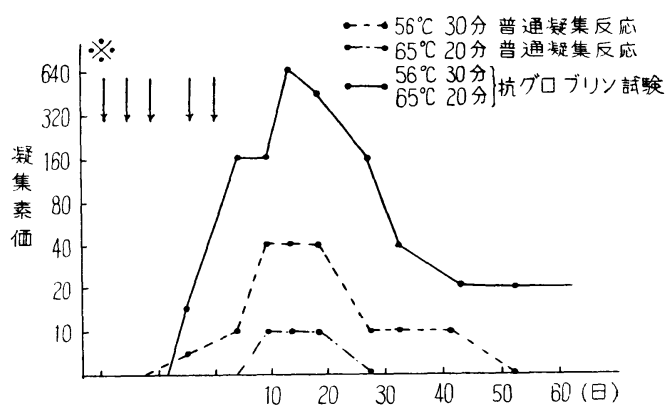

図 1 Sh. dysenteriael 免疫家鬼

$\begin{array}{ccll}\text { ※免疫 } \begin{array}{l}\text { ホルマリンワクチン } \\ \text { II } 0.2 \mathrm{mg} \text { (皮下) }\end{array} & \text { III } & 0.2 \mathrm{mg} \text { (皮下) } \\ \text { IV } 0.5 \mathrm{mg} \text { (腹腔内) } & \text { V } & 0.5 \mathrm{mg} \text { (静脈内) }\end{array}$



図 2 Brucella 感染例に打ける血中抗体

な示唆を含んでいると思う(図 1 )。

プロテウス菌免疫血清 ${ }^{2}$ について ${ }^{3) 4}$

Proteus $\mathrm{O} \mathrm{X}_{19}$ 菌を用いて赤痢菌と同様な実験 を行つたが，この場合には菌体より抽出した多糖 体で動物を免疫した所，菌体を用いた場合とは著 しく様相を異にした現象を示した。

すなわち菌体多糖体は粗製の場合は凝集反応陽 性の完全抗体を産生するが，精製が進むとともに 完全抗体は見られず，不完全抗体のみ産生されて おり，また血球を多糖体で感作したものとのいわ ゆる感作血球凝集反応 (passive hemagglutination) 
よりは補体を加えた場合の溶血反応のみが陽性と なり，溶血抗体と不完全抗体とが密接な関係にあ ることを示しており(第 4 表，第 5 表)進藤らの主 張を裏書きするものであつた。

\section{○ブルセラ菌免疫血清 ${ }^{5}$}

ブルセラ菌を用いる凝集反応は prozone がよ く出現し，実際上困難な事が多い。また，ブルセ ラ症患者よりの菌検出も仲々困難であるので海外 では不完全抗体が注目され始めている。われわ れも，Brucella melitensis，Brucella suis 等を用い て，ヤギを免疫し，あるいは体感染例についてそ の血清中の不完全抗体を検出してみた。この場合 では完全抗体はその消長が極めて不定であるに抱 らず，不完全抗体は長期間存在し，本症の診断や 治療にきわめて重要なものである事を物語つてい る(図 2 )。

\section{まとめ}

上述のごとき種々の腸内細菌を用いて動物を免 疫するときは，従来よりの沈降素や凝集素の外に 不完全抗体が著明に産生されている事が分る。こ の抗体は完全抗体とは異り，耐熱性であり，防禦 抗体としての作用を持つものと考えられるし，ま た溶血抗体と一部洞一でないかとも想像され る。まえがきで述べた様な種々の薬剤を用いた感 染症の場合に注完全抗体の出現する時間的余裕は ないであろうと思われるが不完全抗体の場合は如
何であろうか？ late antibody とされているが， かかる時にも不完全抗体の検出はさらに重要にな るであろう。また比較的小分子の不完全抗体から 通常の大分子の完全抗体一推移寸るか？あるいは 完全抗体が degenerate して不完全抗体に移行す るか? 等はわれわれが日常取扱つている血清中の 抗体は完全抗体と不完全抗体の混合しているもの と考えられるのでなおさら興味深い問題を促供し ているのである。

さらに近時アレルギーやアナフィラキシーの研 究が進むとともに，こ机らにも不完全抗体の介入 を指適する人もあり，血液型抗体において急速に 進歩した不完全抗体の研究は細菌免疫学において も漸く重要視されるに至つている。わが国におけ る不完全抗体の研究は緒についたばかりといえる がその大様は進藤(6)により明解に紹介されてお り御参照願いたい。

\section{文 献}

1) 日比成夫 : 三重医学, 1958, 2457.

2) Morgan, W. T. J. \& Schütze, H: Brit, J. Exp. Path. 1946, 27, 279.

3）野村仲三郎 : 违信医学，1959，11，1327. 同上，1960，12，45.

4) F. Fujita et al. : Mie. Med. J. 1959, 11, 305. Mie. Med. J. 1959, 91, 316. Mie. Med. J. 1959, 11, 324.

5）伊藤徹也：三重医学：1958，2，339.

6）進藤宙二 : 医学の㐫ゆみ，1959，31，555.

7) 進藤宙二等 : 最新医学，1961，16，1078. 